\title{
Does hair coat length affect flea infestation in naturally infested dogs?
}

\author{
A altura da pelagem interfere na população de pulgas em cães naturalmente infestados? \\ Guilherme Araujo Collares da Silva ${ }^{1 *}$; Luciana Araujo Lins ${ }^{1}$; Márcio Josué Costa Irala ${ }^{1}$; Marcial Corrêa Cárcamo²; \\ Paulo Bretanha Ribeiro ${ }^{2}$
}

${ }^{1}$ Faculdade de Medicina Veterinária, Universidade da Região da Campanha - URCAMP, Bagé, RS, Brasil

${ }^{2}$ Instituto de Biologia, Universidade Federal de Pelotas - UFPel, Pelotas, RS, Brasil

Received May 25, 2016

Accepted September 21, 2016

\begin{abstract}
The Siphonaptera are parasitic insects of endothermic animals and Ctenocephalides felis and Pulex irritans are important parasites of dogs. This study evaluated the effect of hair coat length and time of year on the population size of $C$. felis and $P$. irritans in naturally infested dogs. Fleas were collected from 14 dogs on a monthly basis for a year (February 2015 to January 2016) at a rural property in Bagé, Rio Grande do Sul, Brazil. The dogs were divided into two groups based on hair coat length: short coat (coat length $<5.0 \mathrm{~cm}, \mathrm{n}=7$ ) and long coat (coat length $>5.0 \mathrm{~cm}, \mathrm{n}=7$ ). In total, 2057 fleas were collected, 1541 of which were $C$. felis $(74.91 \%)$ and 516 were P. irritans $(25.08 \%)$. The number of $C$. felis and $P$. irritans individuals was significantly affected by hair coat length and time of year. The variation in flea numbers over the study months was higher in long-coated than in short-coated dogs for the two flea species and flea numbers increased with increasing mean monthly temperatures. The results provide a better understanding of behavioral aspects of flea communities in dogs and may help develop control strategies targeting these parasites.
\end{abstract}

Keywords: Ctenocephalides felis, Pulex irritans, flea, dog, behavior.

\section{Resumo}

Sifonápteros são insetos parasitos de animais endotérmicos e Ctenocephalides felis e Pulex irritans são importantes parasitos dos cáes. O objetivo deste trabalho foi avaliar a influência da altura da pelagem de cáes sobre as espécies de pulgas em diferentes meses do ano. Foram coletadas mensalmente, durante um ano, 10 a 15 pulgas em 14 cáes de uma propriedade rural no município de Bagé, RS, Brasil. Os cáes foram divididos em dois grupos: "pelo curto" e "pelo longo", com 07 cães em cada grupo, com altura da pelagem inferior e superior a $5 \mathrm{~cm}$, respectivamente. Coletou-se 2.057 pulgas, 1.541 (74,91\%) C. felis e 516 (25,08\%) P. irritans. O número de indivíduos de C. felis e de P. irritans foi influenciado significativamente, pelo comprimento do pelo dos animais e pelos diferentes meses do ano. Houve maior variação do número de indivíduos das duas espécies, durante os meses, em cães de pelos longos e a curva de aumento populacional acompanhou o aumento das temperaturas médias mensais. Os resultados são importantes para o melhor conhecimento de aspectos comportamentais de comunidades de pulgas em cáes e para o planejamento de estratégias de controle desses parasitos.

Palavras-chave: Ctenocephalides felis, Pulex irritans, pulga, cáo, comportamento.

The Siphonaptera are small, wingless, holometabolous insects that parasitize endothermic animals, especially mammals (LINARDI, 2011). Ctenocephalides felis felis Bouché, 1835 (Pulicidae) is permanent parasite and the primary flea infesting cats and dogs in most of the world (DRYDEN \& RUST, 1994). The human flea, Pulex irritans Linnaeus, 1758, has worldwide distribution and a wide host spectrum and may reach high prevalence rates in dogs,

*Corresponding author: Guilherme Araujo Collares da Silva. Faculdade de Medicina Veterinária, Universidade da Região da Campanha - URCAMP, Rua Mauryti, 146, Esquerda, CEP 96400-260, Bagé, RS, Brasil.

e-mail: guilhermecollares@hotmail.com especially in areas where they are in close contact with humans (DOBLER \& PFEFFER, 2011).

In addition to sucking blood, an estimated $50 \%$ of all dog and cat dermatologic cases referred to veterinary clinics are caused by flea bites (TRAVERSA, 2013). As disease vectors, C. felis and $P$. irritans can be carriers of murine typhus and $P$. irritans plays a significant role in the transmission of plague among humans (BITAM et al., 2010). Fleas of pets, C. felis, C. canis and P. irritans are intermediate hosts of the Dipylidium caninum, a zoonotic cestode, most prevalent in dogs and cats (TRAVERSA, 2013).

Flea populations in dogs are affected by abiotic factors and host density (KRASNOV, 2008). However, little is known about 
the effect of abiotic factors on flea population. Thus, in this study we evaluated the effect of hair coat length and time of year (as a surrogate for temperature) on the population size of $C$. felis and $P$. irritans in naturally infested dogs.

A total of 10 to 15 fleas per dog were collected from 14 dogs on a monthly basis for a year (February 2015 to January 2016) at a rural property in Bagé, Rio Grande do Sul, Brazil (30 $55^{\prime} \mathrm{S}$ and $53^{\circ} 36^{\prime} \mathrm{W}, 145 \mathrm{~m}$ elevation). The property is a cattle, sheep, and goat farm and dogs are used as shepherds (long coat breeds) and hunters (short coat breeds). No ectoparasite control measures were conducted in dogs. The dogs were divided into two groups based on coat length, measured on the dog's back at the base of the neck: short coat, composed of crossbred dogs greyhounds, foxhounds and fox terriers (coat length $<5.0 \mathrm{~cm}, \mathrm{n}=7$ ) and long coat, composed of sheepdogs coming collies and border collies (coat length $>5.0 \mathrm{~cm}, \mathrm{n}=7$ ). Fleas were captured by application of about $100 \mathrm{ml}$ ethanol $92.6 \%$ ABV per animal, directly to the skin along the spinal column. Fleas that left the coat, due to the repulsive effect of alcohol, were collected with histological tweezers and placed in plastic bottles with alcohol $70 \% \mathrm{ABV}$, labeled with the sample number, and later identified by species and sex at the Parasitology Laboratory, University of the Campanha Region (URCAMP), Bagé, RS, Brazil, using the identification key proposed by Bicho \& Ribeiro (1998) and Linardi \& Guimarães (2000).

Mean monthly temperature data for the region were obtained from the National Institute of Meteorology (INMET).

To normalize the data, the number of fleas was square-root $(x+1)$ transformed. Flea numbers of each species were analyzed by two-way analysis of variance (ANOVA) with dog coat length and months as the explanatory variables $(\mathrm{P}<0.05)$. The mean number of fleas per month in each species was compared by the Tukey's test at $\mathrm{P}<0.05$. All analyses were performed using SPSS version 22.0 for Windows (IBM CORPORATION, 2013).

In total, 2057 fleas were collected in the study period (Table 1). Ctenocephalides felis was the most prevalent species (1541, 74.91\%). This species appears to be the most prevalent in this country, because was the only flea species found in Pernambuco, Brazil by
Dantas-Torres et al. (2009) and Minas Gerais, Brazil by Paz et al. (2015), on their respective studies.

P. irritans accounted for $25.08 \%$ of all fleas collected (516/2057). The distribution of $P$. irritans in dogs ranged from $1 \%$ in Greece (KOUTINAS et al., 1995), 7.5\% in Florida, USA (HARMAN et al., 1987) and 19\% in Chile (ALCAÍNO et al., 2002).

Flea numbers were significantly affected by dog coat length (C. felis: $\mathrm{F}=139.20, \mathrm{GL}=1, \mathrm{P}<0.001$, Figure $1 ;$ P. irritans: $\mathrm{F}=108.13, \mathrm{GL}=1, \mathrm{P}<0.001$, Figure 2) and time of year (C. felis: $\mathrm{F}=4.76, \mathrm{GL}=11, \mathrm{P}<0.001$, Figure 1; P. irritans: $\mathrm{F}=3.01$, $\mathrm{GL}=11, \mathrm{P}<0.001$, Figure 2).

The variation in flea numbers over the study months was higher in long-coated than in short-coated dogs for the two flea species. In general, flea numbers for $C$. felis and $P$. irritans increased with increasing mean monthly temperatures (Table 1 ) and a similar pattern has been reported elsewhere (CHRISTODOULOPOULOS et al., 2006; JAFARI SHOORIJEH et al., 2008; PAZ et al., 2015).

Some flea species infesting marsupials exhibit a preference for body areas where hair coat shows different thickness patterns. Xenopsylla skrjabini Ioff, 1930 is found in a negative correlation with hair density on different parts of the body of its host Rhombomys opimus Lichtenstein, 1823 (KRASNOV, 2008). Our study is the first to report the effect of hair coat length on flea abundance in naturally infested dogs, both in the host-specific species $C$. felis and the opportunistic species $P$. irritans, which may be directly related to the adaptation of the species to their host characteristics, namely the ecological, behavioral, physiological, and biochemical aspects of the hosts (POULIN, 2007).

The time spent by flea species on the body of a host is related to circadian and seasonal variation in flea behavior and the physiological status of fleas (KRASNOV, 2008). Our findings indicate that dogs provide better protection from abiotic factors for adult $P$. irritans individuals and immature stages find better conditions for development around the resting sites of dogs.

This study shows that the population dynamics of fleas in naturally infested domestic dogs is affected by hair coat length of the host and temperature variations. These results provide a better

Table 1. Mean monthly temperature and abundance and monthly and total relative frequency of Ctenocephalides felis and Pulex irritans naturally infesting dogs at a rural property in southern Rio Grande do Sul, Brazil.

\begin{tabular}{|c|c|c|c|c|c|}
\hline \multirow{2}{*}{ Month } & \multirow{2}{*}{$\operatorname{Temp}^{\circ} \mathrm{C}$} & \multicolumn{2}{|c|}{ C.felis } & \multicolumn{2}{|c|}{ P. irritans } \\
\hline & & $\mathbf{N}$ & RF (\%) & $\mathbf{N}$ & RF (\%) \\
\hline Jan & 24.63 & 111 & 7.20 & 57 & 11.05 \\
\hline Feb & 23.26 & 139 & 9.02 & 73 & 14.15 \\
\hline Mar & 22.35 & 159 & 10.32 & 29 & 5.62 \\
\hline Apr & 19.29 & 166 & 10.77 & 16 & 3.10 \\
\hline May & 15.90 & 134 & 8.70 & 26 & 5.04 \\
\hline June & 13.69 & 153 & 9.93 & 19 & 3.68 \\
\hline July & 13.10 & 107 & 6.94 & 47 & 9.11 \\
\hline Aug & 17.48 & 113 & 7.33 & 41 & 7.95 \\
\hline Sept & 14.74 & 94 & 6.10 & 63 & 12.21 \\
\hline Oct & 16.00 & 118 & 7.66 & 54 & 10.47 \\
\hline Nov & 19.33 & 125 & 8.11 & 46 & 8.91 \\
\hline \multirow[t]{2}{*}{ Dec } & 22.62 & 122 & 7.92 & 45 & 8.72 \\
\hline & $\sum$ & 1541 & 100.00 & 516 & 100.00 \\
\hline
\end{tabular}

Temp ${ }^{\circ} \mathrm{C}-$ Monthly medium temperatures; $\mathrm{N}$ - number of specimens; RF - relative frequency. 


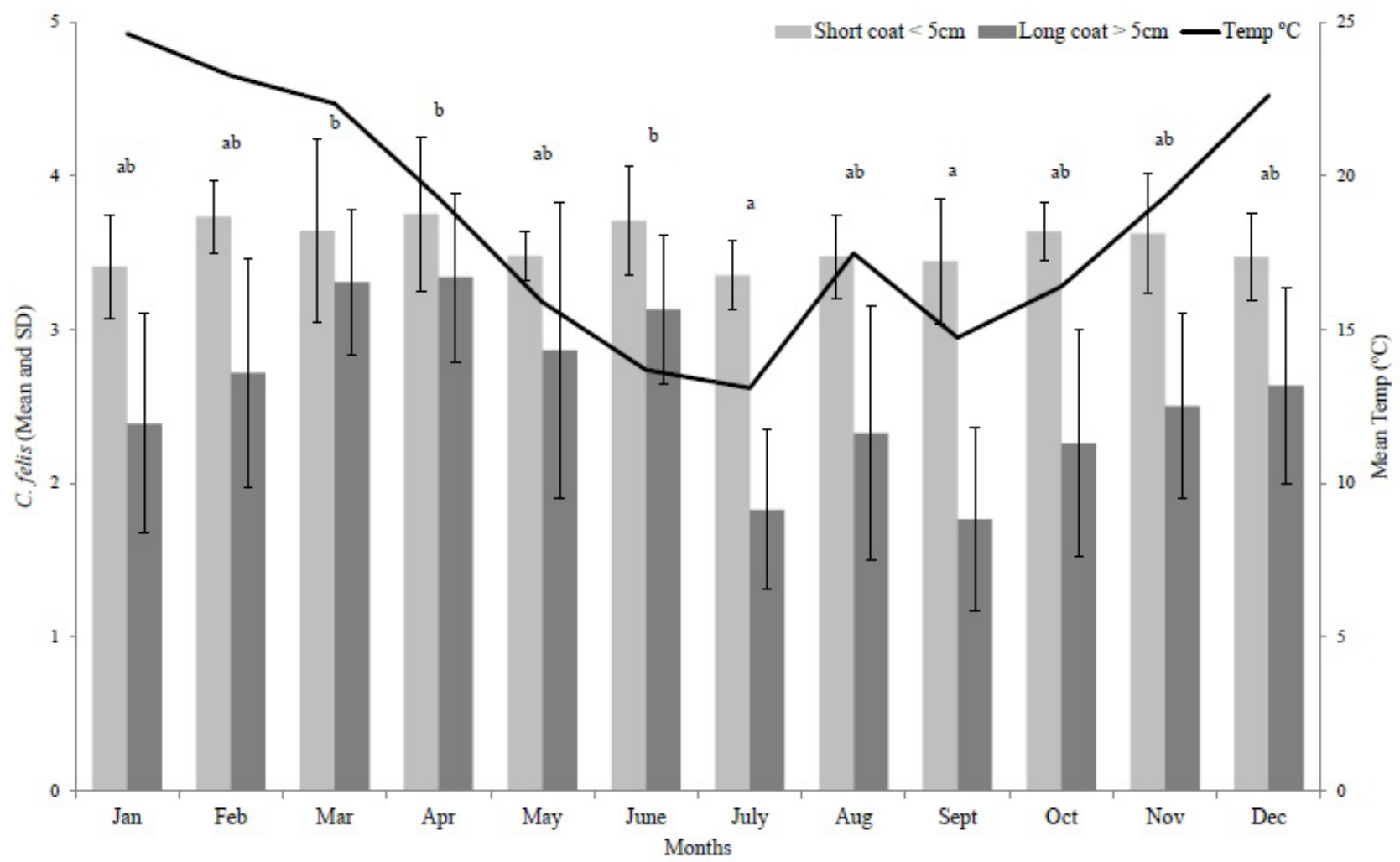

Figure 1. Monthly average distribution of Ctenocephalides felis in short-coated and long-coated dogs and mean monthly temperatures from February 2015 to January 2016 at a rural property in Bagé, Rio Grande do Sul, Brazil. The response variable (number of fleas) was square-root $(\mathrm{x}+1)$ transformed. Means with different letters between months are significantly different by the Tukey's test at $\mathrm{P}<0.05$.

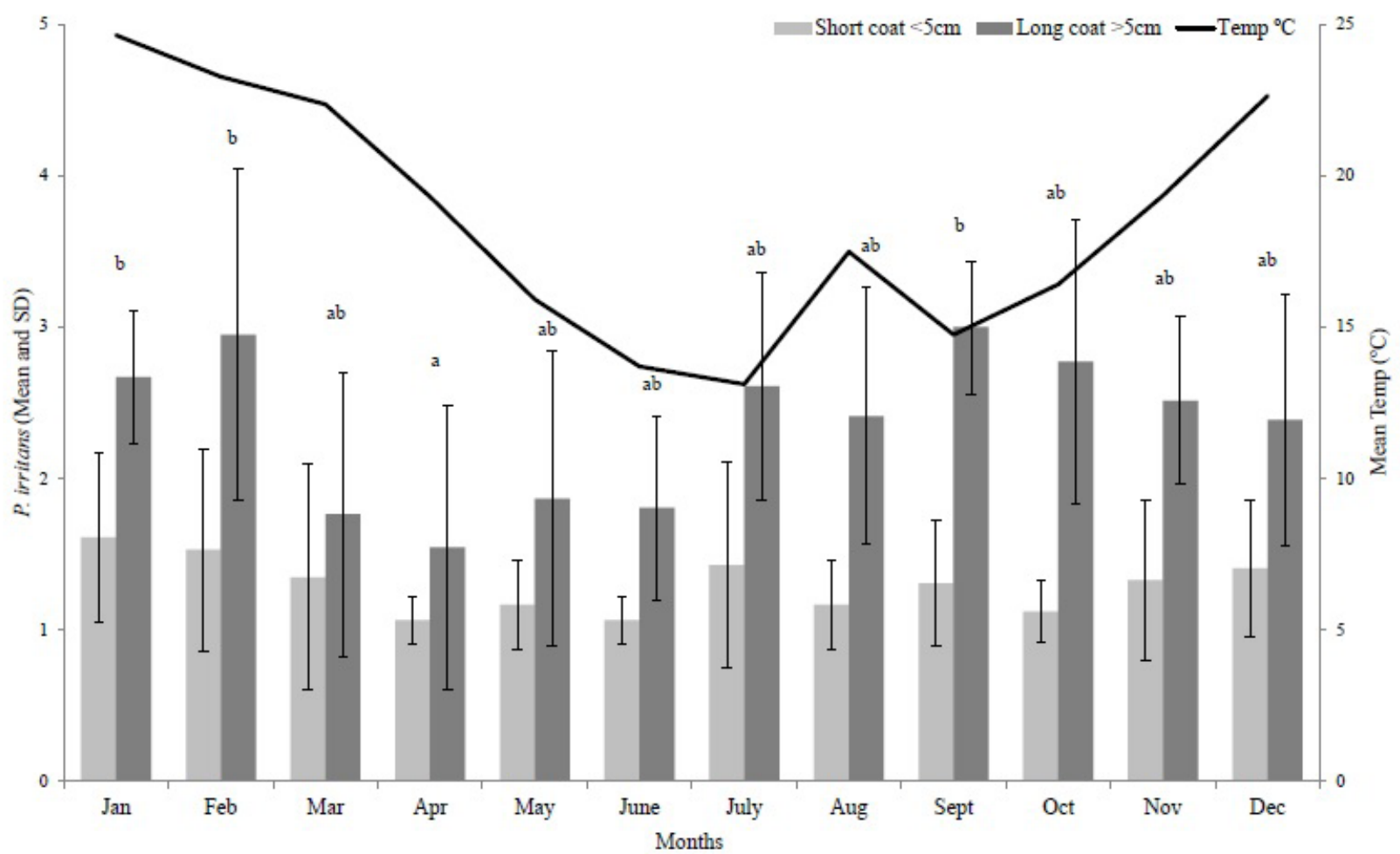

Figure 2. Monthly average distribution of Pulex irritans in short-coated and long-coated dogs and mean monthly temperatures from February 2015 to January 2016 at a rural property in Bagé, Rio Grande do Sul, Brazil. The response variable (number of fleas) was square-root ( $x+1$ ) transformed. Means with different letters between months are significantly different by the Tukey's test at $\mathrm{P}<0.05$. 
understanding of behavioral aspects of flea communities in dogs and may help develop control strategies targeting these parasites, but other aspects should be investigated for a better understanding of the relationship between these ectoparasites and their hosts.

\section{References}

Alcaíno HA, Gorman TR, Alcaíno R. Flea species from dogs in three cities of Chile. Vet Parasitol 2002; 105(3): 261-265. PMid:11934466. http://dx.doi.org/10.1016/S0304-4017(01)00626-4.

Bicho CL, Ribeiro PB. Chave pictórica para as principais espécies de Siphonaptera de importância médica e veterinária, no Brasil. Rev Bras Parasitol Vet 1998; 7(1): 47-51.

Bitam I, Dittmar K, Parola P, Whiting MF, Raoult D. Fleas and fleaborne diseases. Int J Infect Dis 2010; 14(8): 667-676. PMid:20189862. http://dx.doi.org/10.1016/j.ijid.2009.11.011.

Christodoulopoulos G, Theodoropoulos G, Kominakis A, Theis JH. Biological, seasonal and environmental factors associated with Pulex irritans infestation of dairy goats in Greece. Vet Parasitol 2006; 137(1-2): 137-143. PMid:16414195. http://dx.doi.org/10.1016/j. vetpar.2005.12.012.

Dantas-Torres F, Melo MF, Figueredo LA, Brandão-Filho SP. Ectoparasite infestation on rural dogs in the municipality of São Vicente Férrer, Pernambuco, Northeastern Brazil. Rev Bras Parasitol Vet 2009; 18(3): 75-77. PMid:19772781. http://dx.doi.org/10.4322/ rbpv.01803014.

Dobler G, Pfeffer M. Fleas as parasites of the family Canidae. Parasit Vectors 2011; 4(1): 139. PMid:21767354. http://dx.doi.org/10.1186/17563305-4-139.

Dryden MW, Rust MK. The cat flea: biology, ecology and control. Vet Parasitol 1994; 52(1-2): 1-19. PMid:8030176. http://dx.doi. org/10.1016/0304-4017(94)90031-0.
Harman DW, Halliwell RE, Greiner EC. Flea species from dogs and cats in north-central Florida. Vet Parasitol 1987; 23(1-2): 135-140. PMid:3564340. http://dx.doi.org/10.1016/0304-4017(87)90031-8.

IBM Corporation. IBM SPSS Statistics for Windows. Version 22.0 [online]. Armonk: IBM Corp; 2013 [cited 2013 july 23]. Available from: https:// www-01.ibm.com/marketing/iwm/dre/signup?source=SWG-STATSDESKTOP_TRIAL\&S_PKG=ov5354\&S_TACT =000000OA\&S

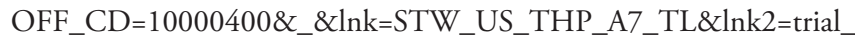
SPSSstat\&lang=en_US

Jafari Shoorijeh S, Rowshan Ghasrodashti A, Tamadon A, Moghaddar $\mathrm{N}$, Behzadi MA. Seasonal frequency of ectoparasite infestation in dogs from Shiraz, southern Iran. Turk J Vet Anim Sci 2008; 32(4): 309-313.

Koutinas AF, Papazahariadou MG, Rallis TS, Tzivara NH, Himonas CA. Flea species from dogs and cats in northern Greece: environmental and clinical implications. Vet Parasitol 1995; 58(1-2): 109-115. PMid:7676591. http://dx.doi.org/10.1016/0304-4017(94)00706-I.

Krasnov BR. Functional and evolutionary ecology of fleas: a model for ecological parasitology. New York: Cambridge University Press; 2008.

Linardi PM, Guimarães LR. Sifonápteros do Brasil. São Paulo: Museu de Zoologia USP/FAPESP; 2000.

Linardi PM. Checklist de Siphonaptera (Insecta) do Estado de São Paulo. Biota Neotrop 2011; 11(S1): 607-617. http://dx.doi.org/10.1590/S167606032011000500027

Paz GF, Avelar DM, Reis IA, Linardi PM. Dynamics of Ctenocephalides felis felis (Siphonaptera: Pulicidae) infestations on urban dogs in southeastern Brazil. JMed Entomol 2015; 52(5): 1159-1164. PMid:26336211. http:// dx.doi.org/10.1093/jme/tjv071.

Poulin R. Are there general laws in parasite ecology? Parasitology 2007; 134(6): 763-776. PMid:17234043. http://dx.doi.org/10.1017/ S0031182006002150.

Traversa D. Fleas infesting pets in the era of emerging extra-intestinal nematodes. Parasit Vectors 2013; 6(1): 59. PMid:23497511. http:// dx.doi.org/10.1186/1756-3305-6-59. 